\title{
New data on the millipede genus Shearia Mikhaljova, 2000 from the Russian and Mongolian Altais (Diplopoda: Chordeumatida: Diplomaragnidae)
}

\section{Новые сведения о двупарноногих многоножках рода Shearia Mikhaljova, 2000 с Русского и Монгольского А^тая (Diplopoda: Chordeumatida: Diplomaragnidae)}

\author{
P.S. Nefediev ${ }^{1,2}$ \\ П.С. Нефедьев ${ }^{1,2}$
}

\footnotetext{
${ }^{1}$ Altai State University, Lenin Avenue 61, Barnaul 656049, Russia. E-mail: p.nefediev@mail.ru

2 Tomsk State University, Lenin Avenue 36, Tomsk 634050, Russia.

${ }^{1}$ Алтайский государственный университет, проспект Ленина 61, Барнаул 656049, Россия.

2 Томский государственный университет, проспект Ленина 36, Томск 634050, Россия.
}

KEY WORDS: Diplopoda, Diplomaragnidae, Shearia, fauna, new records, Siberia, Russia, Mongolia.

КЛЮЧЕВЫЕ СЛОВА: Diplopoda, Diplomaragnidae, Shearia, фауна, новые находки, Сибирь, Россия, Монголия.

ABSTRACT. Based on fresh and re-examined material from SW Siberia, the distributions of five diplomaragnid millipede species of Shearia Mikhaljova, 2000 have been supplemented, refined and updated. The range limits of the following species are expanded: S. khakassica Mikhaljova, 2000 is new to be recorded from the Republic of Altai, S. longa Mikhaljova, 2012 is reported from outside its type locality for the first time, whereas the distribution area of S. oiskaya Mikhaljova, 2000 is limited to the south of the Krasnoyarsk Province. Descriptions of the posterior gonopods of S. calycina Mikhaljova, 2000 and S. khakassica, as well as the diagnosis of the genus in general are supplemented. The distributions of all Shearia species encountered are mapped. A key to all known species of the genus is given.

РЕЗЮМЕ. По новому и повторно изученному коллекционному материалу с юга Западной Сибири дополнены, уточнены и обновлены области распространения для пяти видов диплопод-нитеносцев рода Shearia Mikhaljova, 2000. Расширены ареалы указанных ниже видов: S. khakassica Mikhaljova, 2000 впервые отмечен в Республике Алтай, S. longa Mikhaljova, 2012 - впервые вне типовой территории, между тем как ареал S. oiskaya Mikhaljova, 2000 оказался ограниченным югом Красноярского края. Дополнены описания задних гоноподов S. calycina Mikhaljova, 2000 и S. khakassica, а также диагноз рода в целом. Для всех включённых в настоящую статью видов Shearia выполнено картирование ареалов. Составлен ключ для всех известных видов этого рода.

\section{Introduction}

The millipede genus Shearia Mikhaljova, 2000 is currently known to be represented by eight species, which mainly occur in the south of western and central Siberia, as well as western Mongolia [Mikhaljova, 2000, 2012, 2017]. This genus differs from other genera of Diplomaragnidae Attems, 1907 mainly in a (sub)cyathiform shape of the colpocoxites of the posterior gonopods.

SEM micrographs were prepared at the Laboratory of Aquatic Ecology, Institute for Water and Environmental Problems, Siberian Branch, Russian Academy of Sciences, Barnaul, Russia (IWEP), using a Hitachi S$3400 \mathrm{~N}$ scanning electron microscope. Mounts for SEM were made through air-drying, mounting on stubs, and coating with platinum. SEM material was removed from stubs and returned to alcohol after examination. Digital images were prepared with the help of Helicon Focus 6 image stacking software. The distribution maps were composed using QGIS 3.4.4.

The material treated herein has been deposited in the collection of the Altai State University, Barnaul, Russia (ASU). Literature references to the species concern their distribution areas.

How to cite this article: Nefediev P.S. 2019. New data on the millipede genus Shearia Mikhaljova, 2000 from the Russian and Mongolian Altais (Diplopoda: Chordeumatida: Diplomaragnidae) // Russian Entomol. J. Vol.28. No.2. P.219 -225. doi: 10.15298/rusentj.28.2.16 
Taxonomic part

\section{Class Diplopoda Family DIPLOMARAGNIDAE Shearia calycina Mikhaljova, 2000 Figs 1-7.}

Shearia calycina Mikhaljova, 2000: 166, 167: figs.

Shearia calycina - Mikhaljova, Golovatch, 2001: 110; Mikhaljova, 2004: 163, figs, 164: map; 2017: 200, 201: figs, 134: map; Nefediev, Nefedieva, 2007: 162; Mikhaljova et al., 2008: 53.

MATERIAL EXAMINED. $5 \sigma^{7} \sigma^{7}, 1$, 8 juv., Russia, Republic of Altai, Kosh-Agach District, 26 air-km NNW of Belyashi (Dzhazator), floodplain of Karagem River, on left bank near bridge, $49.88593^{\circ} \mathrm{N}, 87.19024^{\circ} \mathrm{E}$, valley Populus forest with Larix sibirica, ca 1355 m a.s.1., in litter, 29.VII.2018, leg. P.S. Nefediev.

DISTRIBUTION. This species inhabits SE districts of the Republic of Altai only (Fig. 1).

REMARKS. Endemic to the Russian Altais. Neither the gonopods nor coxae 10 , nor coxae 11 of this species have ever been shown using SEM. Therefore, they are given here (Figs 2-7). An examination of males of the species from the ASU collection has revealed a small, two-branched anterior process (ap) on each angiocoxite of the posterior gonopods. This character is well visible in a SEM micrograph (Fig. 4), but it was not specified in the original description [see Mikhaljova, 2000]. Hence, this structure must be included into the description of $S$. calycina.
Shearia densecava (Gulička, 1972)

Figs 1, 8-13.

Altajosoma densecavum Gulička, 1972: 38, 37: fig

Altajosoma densecavum — Lokšina, Golovatch, 1979: 382; Nefediev, Nefedieva, 2008a: 117

Diplomaragna densecava — Shear, 1990: 38; Mikhaljova, 1993: 22.

Shearia densecava - Mikhaljova, 2000: 165, 166: figs; 2004 : 165, figs, 164: map; 2013: 7; 2017: 201, 202: figs, 140: map; Mikhaljova, Golovatch, 2001: 110; Mikhaljova, Nefediev, 2003: 86; Nefediev, Nefedieva, 2007: 162; 2008b: 62; 2013: 87; Mikhaljova et al., 2008: 53; Nefedieva, Nefediev, 2008: 123 .

MATERIAL EXAMINED. $1 \sigma^{7}$, Russia, Republic of Altai, Ulagan District, ca 15 air-km NNW of Aktash, Lake Taldu-Kiol, $50.442703^{\circ} \mathrm{N}, 87.535550^{\circ} \mathrm{E}$, Larix sibirica forest, ca $1840 \mathrm{~m}$ a.s.1., 17-18.VII.2006, leg. P.S. Nefediev, J.S. Nefedieva; $2 \mathrm{O}^{\top} \mathrm{O}^{\top}$, same Republic and District, Kuraiskii Mt. Range, watershed of Korumduairy and Yarlyamry rivers, $50^{\circ} 20^{\prime} \mathrm{N}, 87^{\circ} 43^{\prime} \mathrm{E}$, Pinus sibirica forest, in stumps, ca $2000 \mathrm{~m}$ a.s.1., 7.VIII.2016, leg. Yu.V. Dyachkov; 107,2 우, 1 juv., same Republic, Shebalino District, 3.5 air-km SE of Topuchaya, $51.11189^{\circ} \mathrm{N}, 85.63219^{\circ} \mathrm{E}$, Betula pendula, Larix sibirica, Pinus sibirica and Picea obovata forest with Alnus, Lonicera, Ribes nigrum and tall grass vegetation on hummocks, along brook, $1435 \mathrm{~m}$ a.s.l., hand sampling, sifted leaf litter, pitfall traps, 20-22.VII.2018, leg. P.S. Nefediev, V.I. Gusarov, M.F. Maurstad, V. Løveng.

DISTRIBUTION. This species is known only from the Republic of Altai, occurring in its northern, central and SE districts (Fig. 1).

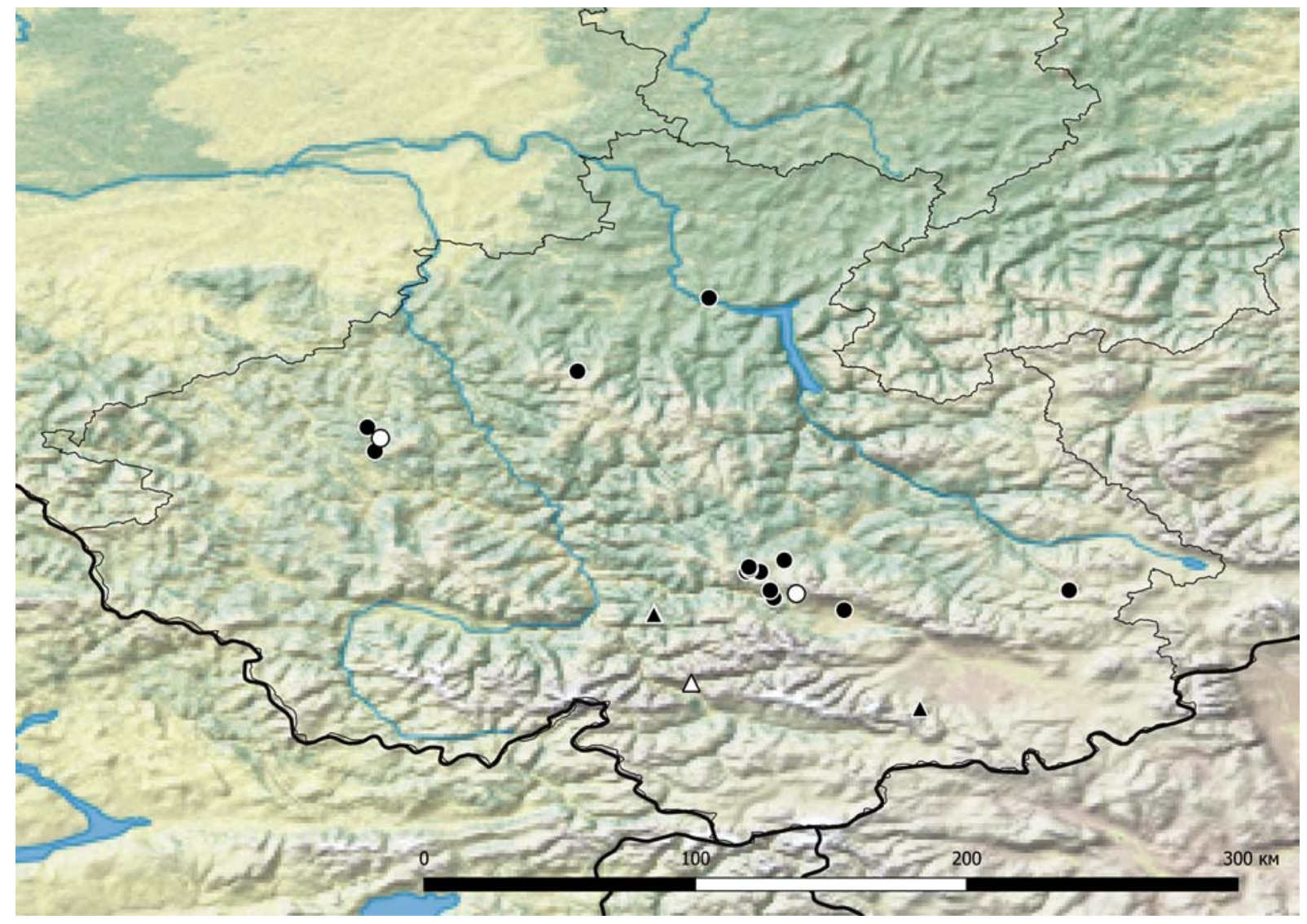

Fig. 1. Distribution of Shearia calycina (triangle) and S. densecava (circle). Previously known localities marked in black, new records given in white.

Рис. 1. Распространение Shearia calycina (треугольник) и S. densecava (круг). Чёрным отмечены ранее известные места находок, новые находки отмечены белым. 
REMARKS. Endemic to the Russian Altais. Neither the gonopods nor coxae 10, nor coxae 11 of this species have ever been shown using SEM. Therefore, they are given here (Figs 8-13).

\section{Shearia khakassica Mikhaljova, 2000} Figs 14-20.

Shearia khakassica Mikhaljova, 2000: 163, figs.

Shearia khakassica - Mikhaljova, Golovatch, 2001: 110; Mikhal-
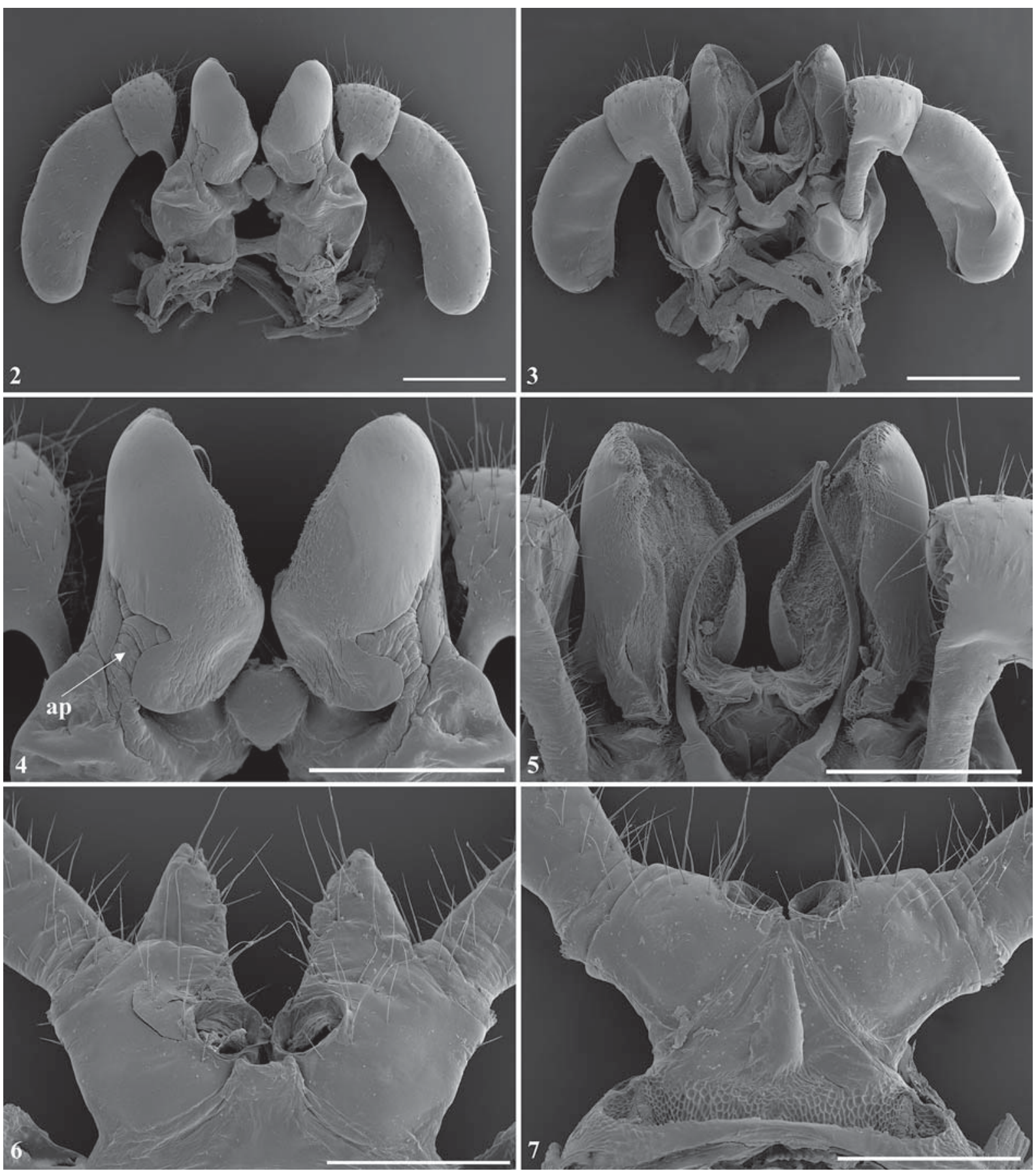

Figs 2-7. Shearia calycina, male (Republic of Altai, floodplain of Karagem River): 2-5 — gonopods; 6 - coxae 10; 7 — coxae 11;2, 4, 6-7 - oral view; 3-5 - caudal view. Scale bars: $1 \mathrm{~mm}(2-3), 0.4 \mathrm{~mm} \mathrm{(4-5)} \mathrm{and} 0.3 \mathrm{~mm}(6-7)$. Designations explained in text.

Рис. 2-7. Shearia calycina, самец (Республика Алтай, пойма р. Карагем): 2-5 — гоноподы; 6 - коксы 10-й пары ног; 7 - коксы 11-й пары ног; 2, 4, 6-7 - спереди; 3-5 - сзади. Масштаб: 1 мм (2-3), 0,4 мм (4-5) и 0,3 мм (6-7). Объяснение обозначений дано в тексте.

jova, 2004: 166, 167: figs, 164: map; 2016: 13; 2017: 202, 203: figs, 140: map; Nefediev, Nefedieva, 2006: 98; 2007: 161; 2008b: 62

Shearia oiskaya - Mikhaljova et al., 2008: 54. Lak-Yyash Lakes, Betula rotundifolia thicket, $50.393970^{\circ} \mathrm{N}$, $89.674179^{\circ} \mathrm{E}, 2200 \mathrm{~m}$ a.s.1., 27.VII.2006, leg. P.S. Nefediev, J.S. Nefedieva.

MATERIAL RE-EXAMINED (specimens previously identified as Shearia oiskaya Mikhaljova, 2000 and published by Mikhaljo-

3
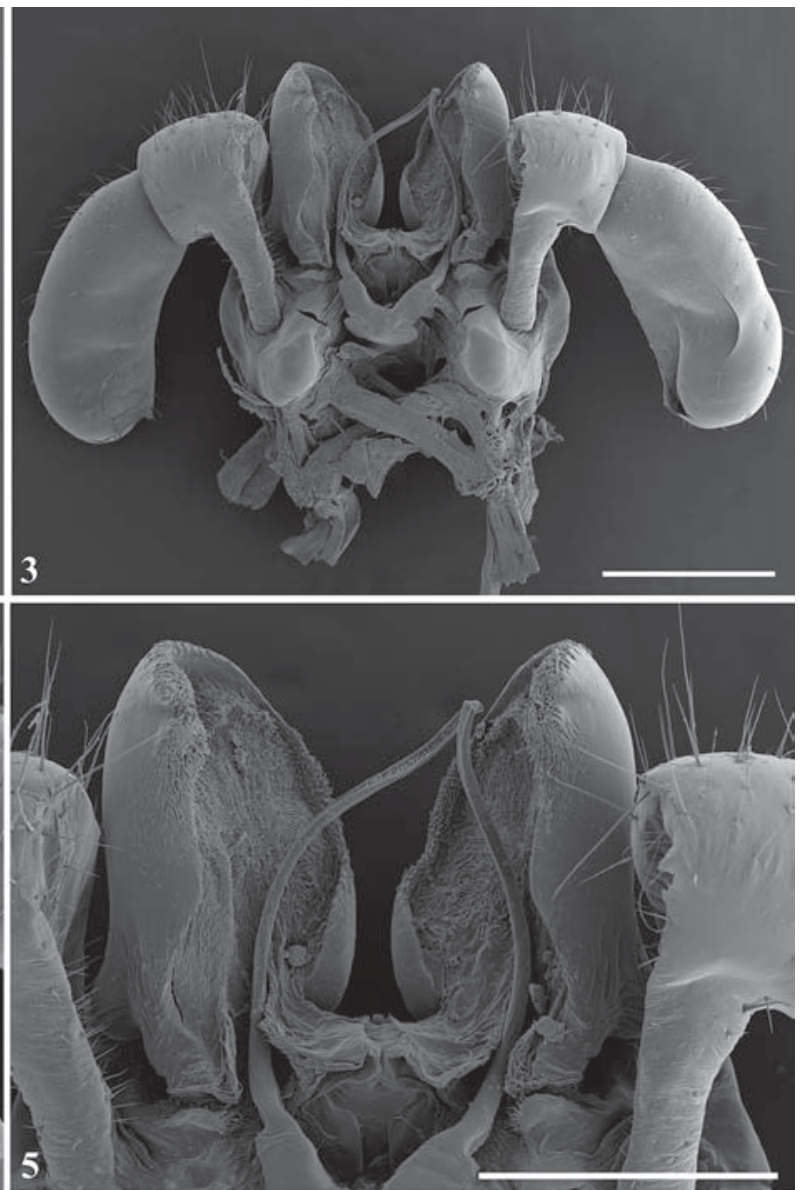
va et al. [2008]). $7 O^{2} O^{7}, 2$ 2 , 22 juv., Russia, Republic of Altai, Ulagan District, $9 \mathrm{~km} \mathrm{~S}$ of Lake Dzhulukul, near Lak-Yyash Lakes, Betula rotundifolia thicket, $50.393970^{\circ} \mathrm{N}, 89.674179^{\circ} \mathrm{E}, 2200 \mathrm{~m}$ a.s.1., 27.VII.2006, leg. P.S. Nefediev, J.S. Nefedieva.

DISTRIBUTION. This species is rather widespread in the south of western and central Siberia (W districts of the Republic of Khakassia, S districts of the Kemerovo Area and the Krasnoyarsk Province, as well as SE districts of the Republic of Altai) (Fig. 14).
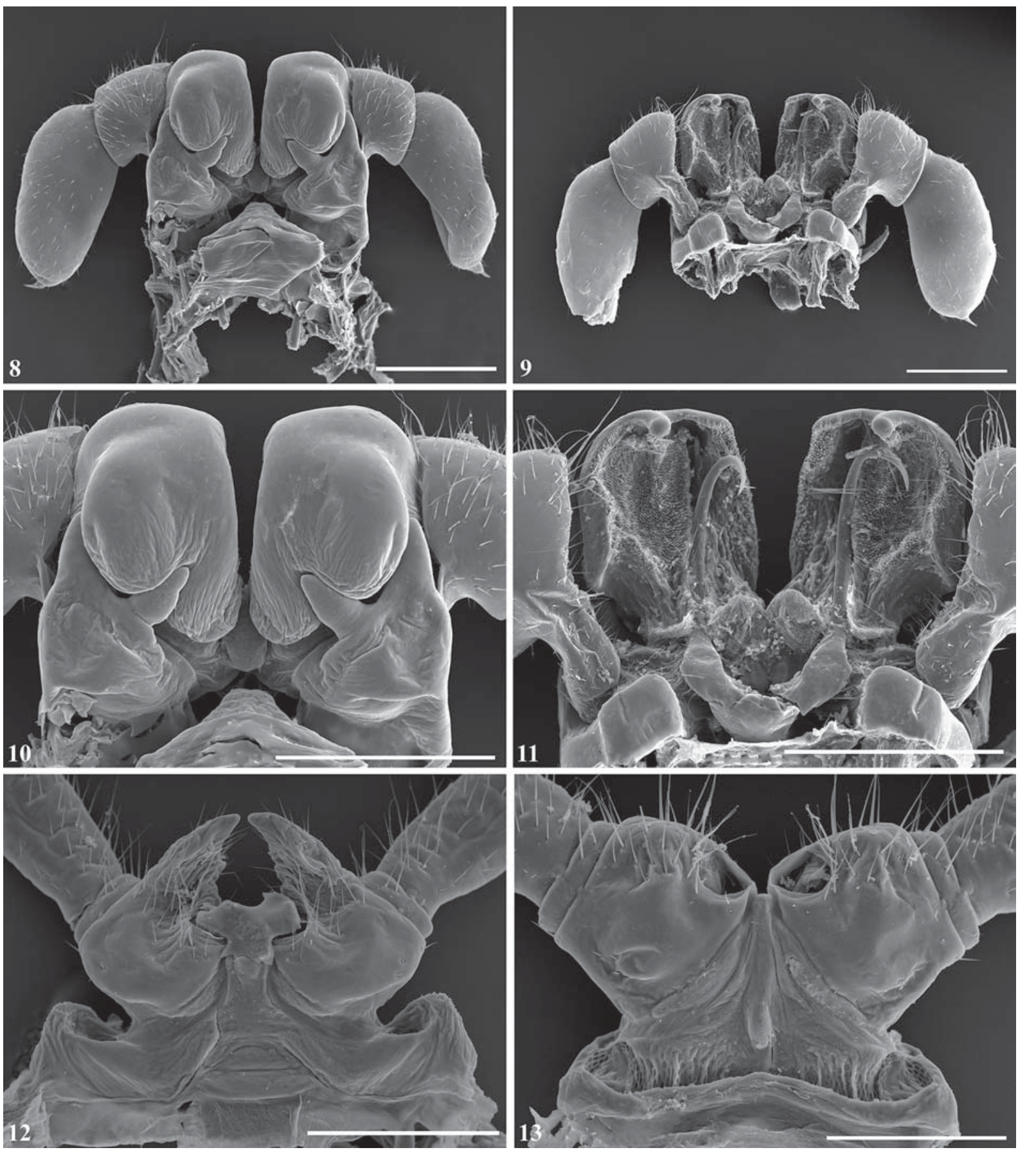

Figs 8-13. Shearia densecava, male: 8 -11 - gonopods; 12 - coxae 10;13 - coxae 11; 8, 10,12-13 - oral view; 9, 11 - caudal view $(8,10,12-13$ - Republic of Altai, Lake Taldu-Kiol; 9, 11 - Republic of Altai, Kalbakaya River). Scale bars: $1 \mathrm{~mm}(8-11), 0.4 \mathrm{~mm}$ (12) and $0.3 \mathrm{~mm}(13)$.

Рис. 8-13. Shearia densecava, самец: 8-11 — гоноподы; 12 - коксы 10-й пары ног; 13 - коксы 11-й пары ног; 8, 10, 12-13 спереди; 9, 11 - сзади $(8,10,12,13$ - Республика Алтай, оз. Талду-Кёль; 9, 11 - Республика Алтай, р. Калбакая). Масштаб: 1 мм $(8-11), 0,4$ мм (12) и 0,3 мм (13).

REMARKS. A restudy of specimens from near LakYyash Lakes at the border of the Republic of Altai and the Republic of Tyva, previously identified as Shearia oiskaya Mikhaljova, 2000 by Mikhaljova et al. [2008], shows that all of them actually belong to $S$. khakassica. The above ernmost records of the species are new to the Republic of Altai. Neither the gonopods nor coxae 10, nor coxae 11 of
this species have ever been shown using SEM. Hence, they

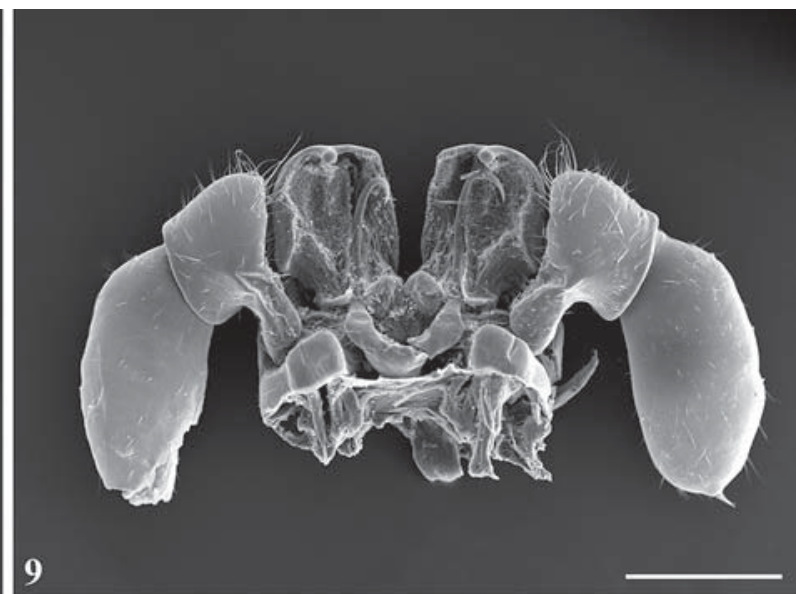


are given here (Figs 15-20). An examination of males of the species from the ASU collection has revealed a small posterior process ( $\mathbf{p p})$ on each angiocoxite of the posterior gonopods, as opposed to "absent" or "a small fold", specified in the original description [see Mikhaljova, 2000]. This structure is well visible in a SEM micrograph (Fig. 18), and it must be included into the description of S. khakassica.

\section{Shearia longa Mikhaljova, 2012}

Fig. 14.

Shearia longa Mikhaljova, 2012: 42, 43-46: figs.

MATERIAL EXAMINED. $7 \sigma^{7} \sigma^{7}, 2$ 9 , , Mongolia, Bayan-Ölgii Province (Aimag), Altai District (Somon), Tsengel Hayrhan Nuruu Mt. Range, $3 \mathrm{~km} \mathrm{~W}$ of Mt Elt Uul, $48^{\circ} 09^{\prime} \mathrm{N} ; 89^{\circ} 14^{\prime} \mathrm{E}$, screes, under stones, $2700 \mathrm{~m}$ a.s.1., 11.VII.2015, leg. A.A. Fomichev.

DISTRIBUTION. This species is known only from the Mongolian Altais, western Mongolia (Fig. 14).

REMARKS. Originally described from the Tsengel Somon of the Bayan-Ölgii Aimag [see Mikhaljova, 2012], this species is now recorded from outside its terra typica for the first time.

The following key can be proposed to Shearia species. 1(4) Anterior angiocoxal processes of posterior gonopods with very large front branches and small outer ones

2(3) Colpocoxites of posterior gonopods strongly curved caudad, with external lateral lobes

shushenskaya Mikhaljova, 2000

3(2) Colpocoxites of posterior gonopods regularly curved caudad, without external lateral lobes

teletskaya Mikhaljova, 2000

4(1) Anterior angiocoxal processes of posterior gonopods small, both branches equal in height ......................... 5

5 (6) Colpocoxite tips of posterior gonopods with subquadrate excavations rybalovi Mikhaljova, 2000

6(5) Colpocoxite tips of posterior gonopods different ..... 7

7(8) Front branches of anterior angiocoxal processes of posterior gonopods distinctly triangular in shape, with pointed tips (Fig. 17) khakassica

8(7) Front branches of anterior angiocoxal processes of posterior gonopods different, without pointed tips .......... 9

9(12) Colpocoxites of posterior gonopods tapering distally, straight

\section{0}

10(11) Anterior gonopod telopodites very long and twisted

11(10) Anterion.................................................. longa calycina

12(13) Colpocoxites of posterior gonopods broad, concave

13(14)

13(14) Mesal sheath plate small densecava 14(13) Mesal sheath plate very large oiskaya Mikhaljova, 2000

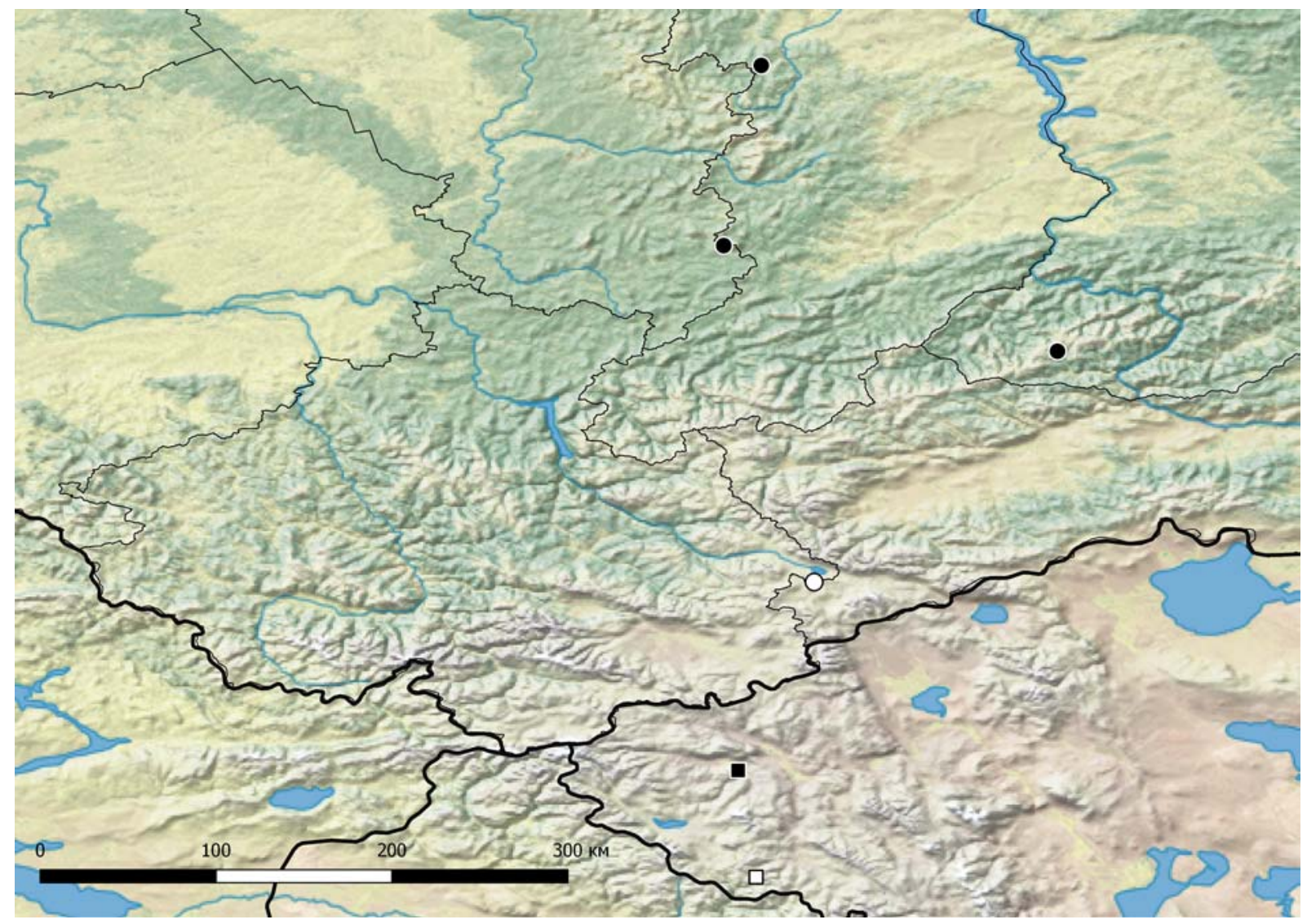

Fig. 14. Distribution of Shearia khakassica (circle) and S. longa (square). Previously known localities marked in black, new records given in white.

Рис. 14. Распространение Shearia khakassica (круг) и S. longa (квадрат). Чёрным отмечены ранее известные места находок, новые находки отмечены белым. 


\section{Conclusions}

New records and restudied material allow for the distributions of five Shearia species to be refined. Shearia khakassica is recorded from the Republic of Altai for the first time, while the range limit of S. oiskaya is restricted to the south of the Krasnoyarsk Province.
Shearia longa is new to be reported from outside its type locality. The presence of a small, two-branched anterior angiocoxal processes (ap) of the posterior gonopods in $S$. calycina must supplement the description of that species, and the diagnosis of the genus in general, i.e. anterior angiocoxal processes of the posterior gonopods always have two branches. The presence of a small
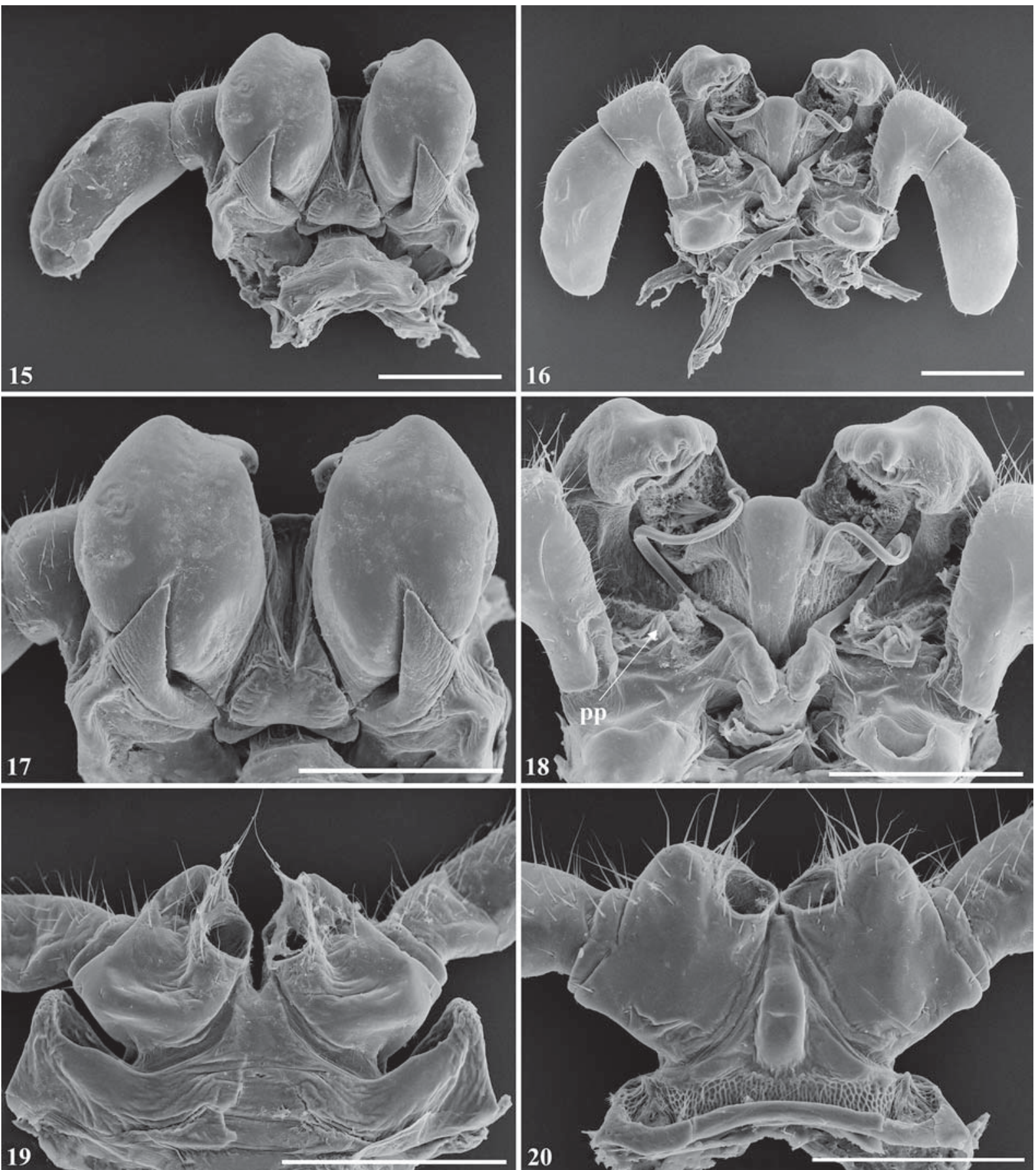

Figs 15-20. Shearia khakassica, male (Republic of Altai, near Lak-Yyash Lakes): 15-18 — gonopods; 19 — coxae 10; 20 — coxae 11; $15,17,19-20$ - oral view; 16, 18 - caudal view. Scale bars: $1 \mathrm{~mm}(15-18)$ and $0.4 \mathrm{~mm}$ (19-20). Designations explained in text.

Рис. 15-20. Shearia khakassica, самец: 15-18 - гоноподы; 19 - коксы 10-й пары ног; 20 - коксы 11-й пары ног; 15, 17, 1920 - спереди; 16, 18 - сзади. Масштаб: 1 мм (15-18) и 0,4 мм (19-20). Объяснение обозначений дано в тексте. 
posterior angiocoxal processes (pp) of the posterior gonopods in $S$. khakassica must supplement the description of that species, and the diagnosis of the genus in general as well, i.e. posterior angiocoxal processes of the posterior gonopods are always present.

Acknowledgements. I am very thankful to S.I. Golovatch (Moscow, Russia) who kindly checked the English of an advanced draft. My deepest gratitude is extended to all persons who provided material for the present study: Yu.V. Dyachkov (Barnaul, Russia), A.A. Fomichev (Novosibirsk, Russia), V.I. Gusarov, M.F. Maurstad, and V. Løveng (all Oslo, Norway). I am very much obliged to V.V. Kirillov (IWEP) who kindly provided the facilities for taking SEM micrographs, as well as to A.V. Dyachenko (IWEP) for the assistance in using the SEM facilities.

\section{References}

Gulička J. 1972. [New millipedes (Diplopoda) from the USSR. Part 2] // Zoologicheskii zhurnal. Vol.51. No.1. P.36-45 [in Russian, with English summary].

Lokšina I.E., Golovatch S.I. 1979. Diplopoda of the USSR fauna // Pedobiologia. Bd.19. S.381-389.

Mikhaljova E.V. 1993. The millipedes (Diplopoda) of Siberia and the Far East of Russia // Arthropoda Selecta. Vol.2. No.2. P.336.

Mikhaljova E.V. 2000. Review of the millipede family Diplomaragnidae (Diplopoda: Chordeumatida) // Arthropoda Selecta (for 1999). Vol.8. No.3. P.153-181.

Mikhaljova E.V. 2004. The millipedes (Diplopoda) of the Asian part of Russia. Sofia-Moscow: Pensoft Publishers. Series Faunistica 39. $292 \mathrm{pp}$.

Mikhaljova E.V. 2012. The class Diplopoda in Mongolia, with description of a new species // Zootaxa. Vol.3418. P.41-50.

Mikhaljova E.V. 2013. New data on the millipede fauna (Diplopoda) of Altai, Russia // Far Eastern Entomologist. No.265. P.1-10.

Mikhaljova E.V. 2016. New species and new records of millipedes (Diplopoda) from the Asian part of Russia // Far Eastern Entomologist. No.316. P.1-25.

Mikhaljova E.V. 2017. [The millipede fauna (Diplopoda) of the Asian part of Russia]. Vladivostok: Dalnauka Publ. 336 pp. [in Russian, with English summary].
Mikhaljova E.V., Golovatch S.I. 2001. A review of the millipede fauna of Siberia (Diplopoda) // Arthropoda Selecta. Vol.9 (for 2000). No.2. P.103-118.

Mikhaljova E.V., Nefediev P.S. 2003. A contribution to the millipede fauna of Siberia (Diplopoda) // Arthropoda Selecta. Vol.11 (for 2002). No.1. P.81-87.

Mikhaljova E.V., Nefediev P.S., Nefedieva J.S. 2008. A new species and new records of millipedes of the family Diplomaragnidae (Diplopoda, Chordeumatida) from Altai // Zootaxa. Vol.1931. P.49-56.

Nefediev P.S., Nefedieva J.S. 2006. [Regional peculiarities of the millipede fauna (Diplopoda) in the south-east of Western Siberia] // V.V. Anyushkin (ed.). Ekologiya Yuzhnoi Sibiri i sopredelnykh territorii. Sbornik materialov X Mezhdenarodnoi shkoly-konferentsii studentov i molodykh uchionykh. Abakan: Khakassian State University Publ. Vol.10. No.1. P.98 [in Russian].

Nefediev P.S., Nefedieva J.S. 2007. [Biogeographical characteristic of the millipede fauna in the southeast of Western Siberia] // G.P. Ostroverkhova (ed.). Bioraznoobrazie bespozvonochnykh zhivotnykh. Sbornik materialov II Vserossiiskoi shkoly-seminara s mezhdunarodnym uchastiem. 24-26 October 2007, Tomsk. Tomsk: Deltaplan Publ. P.159-164 [in Russian].

Nefediev P.S., Nefedieva J.S. 2008a. [A historical review of faunistic investigations of millipedes (Diplopoda) in western Siberia] // V.M. Vazhov (ed.). Altai: ekologiya i prirodopolzovanie. Trudy VII rossiisko-mongolskoi nauchnoi konferentsii molodykh uchionykh i studentov. Vol.1. Biysk: Biysk Pedagogical State University Publ. P.117-120 [in Russian].

Nefediev P.S., Nefedieva J.S. 2008b. Zoogeographical analysis of the millipede fauna (Diplopoda) in the south-east of Western Siberia // Myriapoda and Onychophora of the World Diversity, Biology and Importance. Abstracts of 14th International Congress of Myriapodology. Staatliches Museum für Naturkunde, Görlitz. Peckiana. Vol.6. P.62.

Nefediev P.S., Nefedieva J.S. 2013. [Biodiversity and ecology of millipedes in the environs of Lake Teletskoye (Diplopoda)] // Izvestiya Altaiskogo gosudarstvennogo universiteta, Biologicheskie nauki. Vol.3(79). No.1. P.86-87 [in Russian, with English summary].

Nefedieva J.S., Nefediev P.S. 2008. Ecofaunistical investigations of millipedes (Diplopoda) in the environs of Lake Teletskoe // Myriapoda and Onychophora of the World Diversity, Biology and Importance. Abstracts of 14th International Congress of Myriapodology. Staatliches Museum für Naturkunde, Görlitz. Peckiana. Vol.6. P.123-124.

Shear W.A. 1990. On the Central and East Asian milliped family Diplomaragnidae (Diplopoda, Chordeumatida, Diplomaragnoidea) // American Museum Novitates. No.2977 P.1-40. 